\title{
Penerapan Algoritma Apriori Untuk Analisa Pola Penempatan Barang Berdasarkan Data Transaksi Penjualan
}

\author{
Rizal Amegia Saputra' ${ }^{1}$, Sri Wasiyanti ${ }^{2}$, Rusli Nugraha ${ }^{3}$ \\ 123Universitas Bina Saran Informatika \\ e-mail: rizal.rga@bsi.ac.id, sri.siw@bsi.ac.id, rusli.rng@bsi.ac.id
}

\begin{abstract}
Abstrak
Toko Berkah Baru merupakan toko penjualan berbagai barang-barang plastik dan lain-lain, toko ini memiliki kesulitan dalam penempatan barang, karena banyak jenis barang yang berada ditoko tersebut, menjadi kurang teraturnya posisi barang pada rak, yang mengakibatkan terkadang ada barang yang dicari oleh karyawan tapi malah tidak di temukan di bagian rak, yang berdampak pada kurang baik terhadap pelayanan kepada pembeli. Tujuan penelitian ini menerapkan teknik association data mining yaitu algoritma apriori yang dapat menganalisa transaksi penjualan dari data historis. Pengetahuan baru diperoleh berdasarkan hasil perhitungan algoritma yang diimplementasikan menggunakan aplikasi RapidMiner. Informasi yang didapat dari pengolahan yaitu mengetahui kecenderungan pembeli dalam melakukan pembelian barang yang digunakan untuk memberikan rekomendasi pengadaan barang dan kebijakan tata letak barang berdasarkan intensitas penjualan dalam rangka menunjang aktifitas transaksi penjualan barang. Dari hasil analisa terhadap 31 transaksi penjualan yang menggunakan nilai minimum support sebesar $6 \%$ dan minimum confidence sebesar $60 \%$ didapatkan rekomendasi tata letak barang terhadap klasifikasi penempatan barang yaitu kantong plastik $\rightarrow$ tambang, rodeo $\rightarrow$ sterofom, plastik $9 \times 25 \rightarrow$ karet dan plastik 11x30 $\rightarrow$ sedotan.

Kata Kunci: Apriori, Association Rules, Penempatan Barang
\end{abstract}

\begin{abstract}
The Berkah Baru shop is a shop selling various plastic goods and others, this shop has difficulty in placing goods, because many types of goods are in the shop, the position of goods on the shelves is not orderly, which results in sometimes there are items that employees are looking for. but not even found on the shelf, which has a negative impact on service to buyers. The purpose of this study is to apply association data mining technique, namely a priori algorithm that can analyze sales transactions from historical data. New knowledge is obtained based on the results of algorithm calculations implemented using the RapidMiner application. Information obtained from processing, namely knowing the tendency of buyers to make purchases of goods used to provide recommendations for procurement of goods and policies on layout of goods based on sales intensity in order to support the activity of selling goods. From the results of the analysis of 31 sales transactions using a minimum support value of $6 \%$ and a minimum confidence of $60 \%$, a recommendation for the layout of goods on the classification of goods placement is obtained, namely plastic bag $\rightarrow$ mine, rodeo $\rightarrow$ sterofom, plastic $9 \times 25 \rightarrow$ rubber and plastic $11 \times 30 \rightarrow$ straw.
\end{abstract}

Keywords: Apriori, Association Rules, Placement of Goods

\section{Pendahuluan}

Persaingan dunia bisnis sekarang ini menuntut para pelakunya untuk senantiasa mengembangkan bisnis mereka dan juga agar selalu bertahan dalam persaingan (Nugraha \& Hadiansah, 2017). Untuk mencapai hal itu, ada beberapa hal yang bisa dilakukan yaitu dengan meningkatkan kualitas produk, penambahan jenis produk, pengurangan biaya operasional dan dilakukan analisis data di sebuah toko (Sari \& Sinaga, 2018).

Persaingan dalam pemasaran guna menghasilkan peningkatan pendapatan toko, pihak toko seharusnya dapat mengambil keputusan untuk menentukan strategi pemasaran produk yang dijual. Data-data yang telah tersedia dapat dijadikan sebagai sistem pengambilan keputusan untuk solusi bisnis serta 
dukungan infrastruktur di bidang teknologi yang merupakan penyebab munculnya suatu teknologi data mining. Data mining berguna untuk memberikan solusi kepada para pengambil keputusan dalam bisnis guna meningkatkan bisnis (Thoriq Muhammad \& Nurhadiyono, 2014).

Data mining adalah proses yang menggunaka teknik statistic, matematika kecerdasan buatan, dan machine learning untuk mengekstraksi dan mengindentifikasi informasi yang bermanfaat dan pengetahuan yang terkait dari berbagai database besar (Mardi, 2017). Dalam data mining terdapat beberapa algoritma yang dapat digunakan, salah satunya yaitu Algoritma Apriori yang termasuk dalam aturan asossiasi dalam data mining. Algoritma Apriori bertujuan untuk menemukan frequent itemsets pada sekumpulaan data. Algoritma Apriori didefinisikan suatu proses untuk menemukan suatu aturan Apriori yang memenuhi syarat minimum untuk support dan syarat minimum untuk confidence (Gama, Putra, \& Bayupati, 2016).

Sudah banyak penelitian menggunakan Algoritma Apriori seperti penelitian (Aditya, Marisa, \& Purnomo, 2016) melakukan penerapan algoritma apriori yang outputnya memberikan sebuah rekomendasi produk terlaris kepada pengunjung. Penelitian (Fajri, 2016) melakukan penerapan Apriori dalam menentukan program studi yang diambil mahasiswa. Penelitian yang dilakukan (Gama, Putra, \& Bayupati, 2016), menerapkan algoritma Apriori untuk menemukan frequest itemset dalam sebuah keranjang belanja.

Toko Berkah Baru merupakan sebuah toko yang bergerak dalam bindang penjualan perlengkapan plastik yang memiliki sistem seperti pada swalayan yaitu pembeli mengambil sendiri barang yang akan dibeli lalu melakukan pembayaran di tempat kasir. Peneempatan barang di toko Berkah Baru selama ini tidak tersusun dengan baik sehingga data teersebut hanya berfungsi sebagai arsip bagi toko dan tidak dapat dimanfaatkan untuk pengembangan strategi pemasaran. Data penjualan dapat menjadi acuan untuk rekomendasi penempatan barang agar pelanggan dapat dengan mudah mengambil dan menambahkan barang yang akan dibeli. Hal ini tentu akan mempengaruhi tingkat penjualan barang.

\section{Metode Penelitian}

\section{a. Algoritma Apriori}

Algoritma apriori termasuk kedalam salah satu algortima terbaik dalam data mining. Algoritma apriori banyak digunakan pada data transaksi atau biasa disebut market basket, dengan memiliki fungsi yaitu menemukan pola hubungan antara satu atau lebih atau frequent itemsets pada aturan asosiasi Boolean(Saefudin \& Fernando, 2020).

Penting tidaknya suatu aturan asosiatif dapat diketahui dengan dua parameter, yaitu support dan confidence. Support yaitu persentase kombinasi item tersebut dalam database, sedangkan confidence yaitu kuatnya hubungan antar item dalam aturan asosiasi(Manurung \& Sudarto, 2019).

Metodologi dasar analisis asosiasi (Saefudin \& Fernando, 2020) yaitu:

1. Analisis pola frekuensi tinggi

Pada Tahap ini mencari kombinasi item yang memenuhi syarat minimum dari nilai support dalam database. Nilai support sebuah item diperoleh dengan rumus berikut :

Support $(A)=\frac{\text { Jumlah Transaksi Mengandung } A}{\text { Total Transaksi }}$

Sedangkan nilai support dari 2 item diperoleh dari rumus 2 berikut :

Support $(A, B)=\frac{\sum \text { Transaksi Mengandung } A \text { dan } B}{\sum \text { Transaksi }}$

2. Pembentukan aturan asosiasi

Setelah semua pola frekuensi tinggi ditemukan, kemudian dicari aturan asosiasi yang memenuhi syarat minimum untuk confidence dengan menghitung confidence aturan asosiatif $A \rightarrow B$, Nilai confidence dari aturan $\mathrm{A} \rightarrow \mathrm{B}$ diperoleh dari rumus berikut:

Confidence $=P(B \mid A)=\frac{\sum \text { Transaksi Mengandung } A \text { dan } B}{\sum \text { Transaksi Mengandung } A}$

\section{b. Tahapan Penelitian}

Berikut adalah tahapan penelitian yang dilakukan pada penelitian ini: 


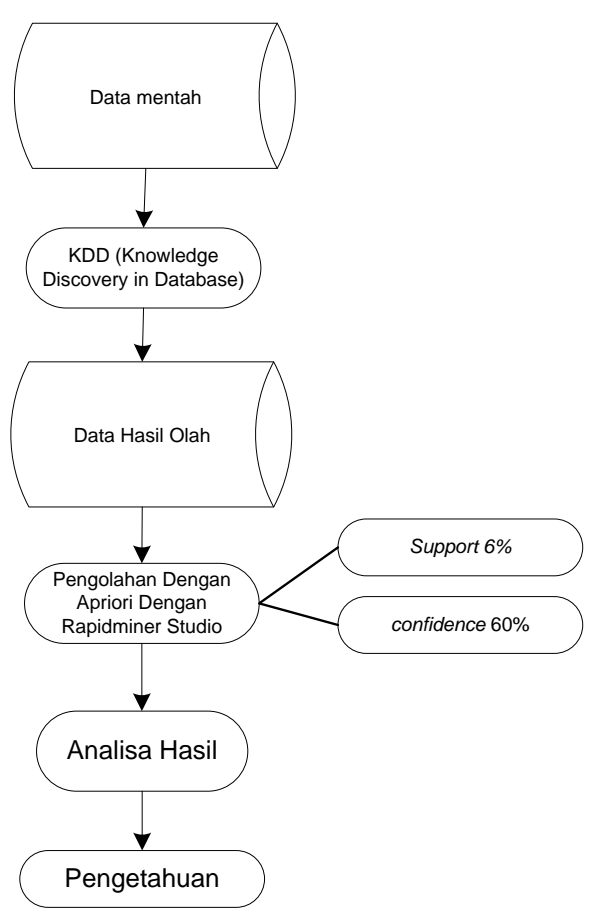

Gambar .1 Tahapan Penelitian

Berdasarkan gambar 1 tahapan penelitian, dapat dijelaskan sebagai berikut: a. Data mentah direduksi terlebih dahulu dan dimasukkan ke dalam CSV untuk menjadi data training.

b. Dengan menggunkan metode KDD data diolah untuk menghilangkan duplikasi, yang sudah tersedia pada software RapidMiner Studio, setelah di remove duplicate menjadi 30 data.

c. Selanjutnya data diuji dengan menggunakan Algoritma Apriori

Tabel 1. Data Transaksi Penjualan

\begin{tabular}{|c|c|c|c|c|c|c|c|c|c|c|c|c|c|c|c|c|c|c|c|c|c|c|c|c|c|c|c|c|c|c|}
\hline \multirow{2}{*}{ Nama Barang } & \multicolumn{29}{|c|}{ Tanggal Transaksi } & \multirow[b]{2}{*}{100} \\
\hline & 1 & & $\begin{array}{l}3.4 \\
\end{array}$ & & 6 & & & 10 & 11 & 12 & 13 & 14 & 15 & 16 & 17 & 18 & 19 & 20 & 21 & 22 & 23 & 24 & $25 \mid 2$ & 26 & 27 & 28 & 293 & 30 & 31 & \\
\hline Kantong & 1 & & c & 0 & 0 & 0 & 0 & 0 & 0 & 0 & 0 & 0 & 1 & 0 & 0 & 0 & 0 & 0 & 의 & 0 & 1 & 1 & 1 & 1 & 1 & 1 & 0 & 1 & 0 & 10 \\
\hline BolaPlastik & 0 & 0 & c & & 0 & 0 & 0 & 0 & 0 & 0 & 0 & 0 & 0 & 0 & 0 & 0 & 0 & 0 & 0 & 0 & 0 & 0 & 0 & 0 & 0 & 0 & 0 & 0 & 0 & 1 \\
\hline KorekGas & 0 & & $0 \mid 1$ & 0 & 0 & 0 & 0 & 0 & 0 & 0 & 0 & 0 & 0 & 0 & 0 & 0 & 0 & 0 & 0 & 0 & 0 & 0 & 0 & 0 & 0 & 0 & 0 & 0 & 0 & 1 \\
\hline Jumbo & 0 & & 0 & & 0 & 0 & 0 & 0 & 0 & 0 & 0 & 0 & 0 & 0 & 0 & 0 & 0 & 0 & 0 & 0 & 0 & 0 & 0 & 0 & 0 & 0 & 0 & 0 & 0 & 1 \\
\hline Rodeo & 0 & 0 & 0 & 0 & 1 & 1 & 0 & 0 & 0 & 0 & 0 & 0 & 0 & 0 & 0 & 0 & 0 & 0 & 0 & 0 & 0 & 0 & 0 & 0 & 0 & 0 & 0 & 0 & 0 & 2 \\
\hline Kertas & 0 & 0 & 0 & & 0 & 0 & 1 & 1 & 1 & 0 & 0 & 0 & 0 & 0 & 0 & 0 & 0 & 0 & 0 & 0 & 0 & 0 & 0 & 0 & 0 & 0 & 0 & 0 & 0 & 4 \\
\hline Vaneli & 0 & 0 & 00 & & 0 & 0 & 0 & 0 & 0 & 1 & 0 & 0 & 0 & 0 & 0 & 0 & 0 & 0 & 0 & 0 & 0 & 0 & 0 & 0 & 0 & 0 & 0 & 0 & 0 & 1 \\
\hline Plastik $4 \times 23$ & 0 & 0 & 00 & & 0 & 0 & 0 & 0 & 0 & 1 & 0 & 0 & 0 & 0 & 0 & 0 & 0 & 0 & 0 & 1 & 0 & 0 & 0 & 0 & 0 & 0 & 0 & 0 & 0 & 2 \\
\hline Plastik $6 \times 20$ & 0 & 1 & 0 & 0 & 0 & 0 & 0 & 0 & 0 & 0 & 0 & 0 & 0 & 0 & 0 & 0 & 0 & 0 & 0 & 0 & 0 & 0 & 0 & 0 & 0 & 0 & 0 & 0 & 0 & 1 \\
\hline Plastik17x40 & 0 & 0 & 10 & 0 & 0 & 0 & 0 & 0 & 0 & 0 & 0 & 0 & 0 & 0 & 0 & 0 & 0 & 0 & 0 & 0 & 0 & 0 & 0 & 0 & 0 & 0 & 0 & 0 & 0 & 1 \\
\hline Plastik $8 \times 20$ & 0 & 0 & $\begin{array}{l}0 \\
0\end{array}$ & 0 & 0 & 0 & 0 & 0 & 0 & 0 & 0 & 0 & 0 & 0 & 0 & 0 & 0 & 0 & 0 & 0 & 0 & 0 & 0 & 0 & 0 & 0 & 0 & 0 & 0 & 1 \\
\hline Plastik9 $\times 25$ & 0 & & 0 & & 0 & 0 & 0 & 0 & 0 & 0 & 1 & 0 & 0 & T & 0 & 0 & 0 & 1 & 0 & 0 & 0 & 0 & 0 & 0 & 0 & 0 & 0 & 0 & 0 & 4 \\
\hline Plastik11x30 & 4 & 0 & c & 0 & 1 & 0 & 0 & 0 & 0 & 0 & 0 & 1 & 0 & 0 & 0 & 0 & 1 & 0 & 0 & 0 & 0 & 0 & 0 & 0 & 0 & 0 & 0 & 0 & 1 & 4 \\
\hline Plastik14×35 & 0 & 0 & 5 & 0 & 0 & 1 & 0 & 0 & 0 & 0 & 0 & 0 & 1 & 0 & 0 & 1 & 0 & 0 & 0 & 0 & 0 & 0 & 0 & 0 & 0 & 0 & 0 & 0 & 0 & 3 \\
\hline lastik10×25 & 0 & 0 & 0 & 10 & 0 & 0 & 0 & 0 & 0 & 0 & 0 & 0 & 0 & 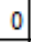 & 0 & 0 & 0 & 0 & 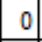 & 0 & 0 & 0 & 0 & 0 & 0 & 0 & 0 & 0 & 0 & 1 \\
\hline
\end{tabular}

d. Analisa hasil dilakukan berdasarkan perhitungan Algoritma Apriori dan analisis hasil dari sistem yang dibangun sehingga menghasilkan keputusan yang dapat digunakan untuk pengambilan keputusan dalam penentuan tata letak barang yang akan dijual.

e. Pengetahuan yang didapat dari hasil analisa Algoritma Apriori dapat menghasilkan kebijakan untuk perusahaan, seperti tata letak penjualan barang.

\section{Hasil dan Pembahasan}

Data yang digunakan pada penelitian ini didapat dari Toko Berkah Baru, hasil transaksi penjualan pada bulan januari 2020. Setelah data dikumpulkan tahapan

\subsection{Data Cleaning}

Berdasarkan Tabel 1 diperoleh tabel transaksi penjualan pada toko berkah baru yang diambil dari transaksi bulan Januari 2020, pada tahap cleaning, data disesuaikan agar dapat di olah dengan Software Rapidminer Studio, data yang dirubah yaitu data barang yang ada transaksi penjualan dirubah menjadi nilai 1 dan apabila tidak ada transaksi penjualan nilainya 0 . Nilai 1 artinya barang yang terjual pada setiap transaksi sedangkan nilai 0 barang tersebut tidak terjual.

Berikut data tabel penjualan bulan Januari tahun 2020 pada Toko Berkar Baru yaitu: 


\begin{tabular}{|c|c|c|c|c|c|c|c|c|c|c|c|c|c|c|c|c|c|c|c|c|c|c|c|c|c|c|c|c|c|c|}
\hline Agers & & 0 & 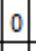 & 0.0 & 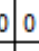 & 0 & & 0 & 0 & 0 & 0 & & 0 & 0 & 0 & & 0 & 0 & 0 & 0 & & & 0 & 0 & & & 0 & & 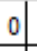 & \\
\hline Nutrijelly & 0 & 0 & 0 & 0.0 & 00 & 0 & & 0 & 0 & 0 & 1 & 0 & 이 & 0 & 0 & 0 & 0 & 0 & 0 & 0 & 0 & 0 & 0 & 0 & 0 & 0 & 0 & 0 & 0 & 1 \\
\hline Dus $18 \times 18$ & c & & 1 & 0 & 0 & 0 & & 0 & $\underline{0}$ & 0 & 0 & 0 & 0 & 0 & 0 & 0 & 0 & 이 & 0 & 0 & 0 & 0 & 0 & 이 & 0 & 0 & 0 & 0 & 0 & 1 \\
\hline Uus $20 \times 20$ & c & 00 & 1 & 1 & $\begin{array}{l}0 \\
0\end{array}$ & 0 & & 0 & 0 & $\underline{0}$ & c & 0 & 0 & 0 & 0 & 0 & 0 & 0 & 0 & 0 & & 0 & $0 \mid$ & 0 & 0 & 0 & 0 & 0 & 0 & 1 \\
\hline edotan & 0 & 0 & 0 & 0 & 10 & 0 & & 0 & 0 & 0 & 0 & 1 & 0 & 0 & 0 & 1 & 0 & 0 & 1 & 0 & 0 & 0 & 0 & 0 & 0 & 0 & 이 & 1 & 1 & 6 \\
\hline Tusul & 0 & 00 & 0 & 0 & 0 & 0 & & 0 & 0 & 0 & $\underline{0}$ & 0 & 0 & 0 & 0 & 0 & 0 & 0 & 0 & 0 & 0 & 0 & 아 & 0 & 0 & 0 & 0 & 0 & 0 & 1 \\
\hline Senda & 0 & 00 & 0 & 0 & 00 & 0 & & U & 0 & 0 & 0 & 0 & 0 & 1 & 0 & 0 & 0 & 0 & 0 & 이 & 0 & 0 & 0 & 0 & 0 & 0 & 0 & 0 & 0 & 2 \\
\hline Solas & 0 & 00 & 0 & 0 & 00 & 0 & & & 0 & 0 & 0 & 0 & 0 & 0 & 0 & 0 & 0 & 0 & 0 & 0 & 이 & 이 & 0 & 0 & 0 & 0 & 0 & 0 & 0 & 1 \\
\hline la & 0 & 00 & $|0|$ & 0 & 00 & 0 & & 0 & 1 & 0 & 0 & 0 & 의 & 0 & 0 & 0 & 0 & 0 & 0 & 0 & 0 & 0 & 이 & 0 & 0 & 0 & 0 & 0 & 0 & 1 \\
\hline TaliRapia & 0 & 00 & 0 & 1 & 00 & 0 & & 0 & 0 & 0 & 0 & 0 & 0 & 0 & 0 & 0 & 0 & 0 & 0 & 0 & 요 & 0 & 0 & 0 & 0 & 0 & 0 & 0 & 1 & 2 \\
\hline Stero & 0 & 00 & 0 & 0 & 11 & 0 & & 0 & 0 & 0 & 0 & 0 & 0 & 0 & 0 & 0 & 0 & 0 & 0 & 0 & 0 & 0 & 0 & 0 & 0 & 0 & 0 & 0 & I & 3 \\
\hline GilentKun & 0 & 00 & 0 & 0 & 00 & 0 & & 0 & & 0 & 1 & 0 & 0 & 0 & 0 & 0 & 0 & 0 & 이 & 이 & 0 & 0 & 0 & 0 & 0 & 0 & 0 & 1 & 0 & 3 \\
\hline GiletE & 0 & 00 & 0 & 0 & 00 & 0 & & 0 & 0 & 0 & 0 & 0 & 0 & 0 & 0 & 0 & 0 & 0 & 0 & 0 & 0 & 0 & 0 & 0 & 0 & 0 & 1 & 0 & 0 & 1 \\
\hline iret & 0 & 00 & 0 & 0 & 00 & 0 & & 0 & & 0 & 1 & 1 & 0 & 0 & 0 & 0 & 0 & 11 & 0 & 0 & 0 & 이 & 0 & 0 & 0 & 0 & 0 & 0 & 0 & 3 \\
\hline tint & 0 & 00 & 0 & 0 & 00 & 0 & & 0 & & 0 & 0 & 0 & 0 & 0 & 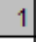 & 4 & 1 & 의 & 0 & 0 & 의 & & 0 & 0 & 0 & 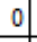 & 0 & 0 & 0 & 3 \\
\hline Cele & 0 & 00 & 0 & 0 & 00 & 0 & & 0 & 0 & 0 & 0 & 0 & 0 & 0 & 0 & 0 & 0 & 1 & 1 & 1 & 0 & & 0 & 0 & 0 & 0 & 0 & 0 & 0 & 3 \\
\hline IsiSteples & 0 & & 0 & 0 & 00 & 0 & & 0 & 0 & 0 & 0 & 0 & 0 & 0 & 0 & 0 & 0 & 0 & 0 & 0 & 1 & 0 & 0 & 0 & 0 & 0 & 0 & 0 & 0 & 1 \\
\hline Tambang & 0 & 00 & 0 & 0 & $\begin{array}{lll}0 & 0 \\
\end{array}$ & 0 & & 0 & 0 & 0 & 0 & 0 & 0 & 0 & 0 & 0 & 0 & 0 & 0 & 0 & 0 & 1 & 1 & 1 & 0 & 0 & 0 & 0 & 0 & 3 \\
\hline Amplop & 0 & 00 & 0 & 0 & $\begin{array}{ll}0 & 0 \\
\end{array}$ & 0 & 0 & 0 & 0 & 0 & 0 & 0 & 0 & 0 & 0 & 0 & 0 & 0 & 0 & 0 & 0 & 0 & 0 & 0 & 1 & 0 & 0 & 0 & 0 & 1 \\
\hline Lemc & 0 & 00 & 0 & 0 & \begin{tabular}{l|l}
0 & 0 \\
\end{tabular} & 0 & 0 & 0 & 0 & 0 & 0 & 0 & 0 & 0 & 0 & 0 & 0 & 0 & 0 & 0 & 0 & 0 & 0 & 0 & 0 & 1 & 0 & 0 & $\underline{0}$ & 1 \\
\hline Penge & 0 & 00 & 0 & 0 & $\begin{array}{ll}0 & 0 \\
\end{array}$ & 0 & 0 & 0 & & 이 & 0 & 0 & 0 & 0 & 1 & 0 & of & 0 & 0 & 0 & 0 & & 0 & 0 & 0 & 0 & 0 & 0 & I & 1 \\
\hline & 0 & 00 & 0 & 0 & \begin{tabular}{l|l}
0 & 0 \\
\end{tabular} & 0 & & 0 & 0 & 0 & 0 & 0 & 0 & 0 & 0 & 0 & 0 & 0 & 1 & 0 & 0 & 0 & 0 & 0 & 0 & 0 & 0 & 0 & 0 & 1 \\
\hline Citrun & 0 & 00 & 0 & 0 & $\begin{array}{ll}0 & 0 \\
\end{array}$ & 0 & & 0 & 0 & 0 & 0 & 0 & 0 & 0 & 0 & 0 & 0 & 0 & 0 & 1 & 0 & 0 & 0 & 0 & 0 & 0 & 0 & 0 & 0 & 1 \\
\hline Mika & 0 & 00 & 0 & 0 & $\begin{array}{ll}0 & 0 \\
\end{array}$ & 0 & & 0 & 0 & 0 & 0 & 0 & 0 & 0 & 0 & 0 & 0 & 0 & 0 & 0 & 1 & 0 & 0 & 0 & 0 & 0 & \begin{tabular}{|lll} 
& \\
\end{tabular} & 1 & 0 & 3 \\
\hline Pasta & 0 & 00 & 0 & 0 & \begin{tabular}{l|l}
0 & 0 \\
\end{tabular} & 0 & 0 & 0 & 0 & 0 & 아 & 0 & 0 & 1 & 0 & 0 & 0 & 0 & 0 & 이 & 0 & 0 & 0 & 0 & 0 & 0 & 0 & 0 & 0 & 1 \\
\hline Karpet & 4 & 00 & 0 & 0 & \begin{tabular}{l|l}
0 & 0 \\
\end{tabular} & 0 & 0 & 0 & 0 & 0 & 0 & 0 & 0 & 0 & 1 & 0 & 0 & 0 & 0 & 0 & 0 & 0 & 0 & 0 & 0 & 0 & 0 & 0 & 0 & 1 \\
\hline Rola & 0 & 00 & 0 & 0 & \begin{tabular}{l|l}
0 & 0 \\
\end{tabular} & 0 & & 0 & 0 & 0 & 0 요 & 0 & 0 & 0 & 0 & 0 & 0 & 1 & 0 & 0 & 0 & 0 & 0 & 0 & 0 & 1 & 0 & 0 & 0 & 2 \\
\hline Mangk & $t_{2}$ & 00 & 4 & 0 & \begin{tabular}{l|l}
0 & 0 \\
\end{tabular} & 0 & & - & $\underline{0}$ & 0 & 0 & 0 & 0 & 0 & 1 & 0 & 0 & 0 & 0 & 0 & 0 & 1 & 0 & 1 & 0 & 0 & 0 & 1] & 0 & 5 \\
\hline Sen & 0 & 00 & 0 & 0 & $\begin{array}{lll}0 & 0 \\
\end{array}$ & 1 & 0 & 0 & 0 & 0 & 0 & 0 & 1 & 0 & 0 & 0 & 1 & 0 & 0 & 0 & 0 & 0 & 0 & 0 & 0 & 0 & 1 & 0 & 0 & 4 \\
\hline Gelas $12 \mathrm{ml}$ & 1 & 00 & & 0 & \begin{tabular}{l|l}
0 & 0 \\
\end{tabular} & 0 & & 0 & 0 & 0 & 0 & 0 & 0 & 0 & 0 & 0 & 0 & 0 & 0 & 0 & 0 & 0 & 0 & 0 & 0 & 0 & 0 & 0 & 0 & 2 \\
\hline Gela & 0 & 1 & 0 & 1 & \begin{tabular}{l|l}
0 & 0 \\
\end{tabular} & 0 & 0 & 0 & 0 & 0 & 0 & 0 & 0 & 0 & 0 & 0 & 0 & 0 & 0 & 0 & 0 & 0 & 0 & 0 & 0 & 0 & 0 & 0 & 0 & 2 \\
\hline TutupGelas & 4 & 00 & 0 & 0 & $\begin{array}{lll}0 & 0 \\
\end{array}$ & 0 & $\begin{array}{ll}0 & \mathrm{C} \\
\end{array}$ & 0 & 0 & 0 & 0 & 0 & 0 & 0 & 0 & $\mathrm{~T}$ & 0 & 0 & 0 & 0 & 0 & 0 & 0 & 0 & 0 & 0 & 0 & 0 & 0 & 1 \\
\hline SekatPlastik & 0 & 0 & 4 & 0 & $\begin{array}{lll}0 & 0 \\
\end{array}$ & 1 & 0 & 0 & 0 & 0 & 아 & 0 & 0 & 0 & 0 & 1 & 0 & 0 & 0 & 0 & 0 & 0 & $\begin{array}{ll}0 \\
\end{array}$ & 0 & 1 & 0 & 0 & 0 & 0 & 3 \\
\hline GelasKopi & 4 & $\begin{array}{ll}0 & 1 \\
\end{array}$ & + & 0 & 00 & 0 & & 0 & 0 & 0 & 0 & 0 & 0 & 0 & 0 & 0 & 0 & 0 & 0 & 0 & 0 & 0 & 0 & 0 & 0 & 0 & 0 & 0 & 0 & 2 \\
\hline elas $16 \mathrm{ml}$ & 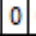 & 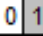 & 0 & 00 & $\begin{array}{lll}0 & 0 \\
\end{array}$ & 10 & 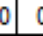 & U] & & 1 & 4 & 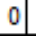 & $0_{1}$ & 0 & 0 & 0 & 0 & 1 & 0 & 0 & 1 & & L 0 & 01 & 0 & 证 & 0 & 0 & 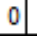 & \\
\hline
\end{tabular}

\subsection{Data Integration}

Pada tahap integrasi data dilakukan penggabungan data yang semula berupa penjualan menjadi sebuah database. Tujuan penggabungan data ini yaitu untuk mempermudah seleksi data sesuai dengan kebutuhan penelitian.

\subsection{Data Selection}

Pada tahap seleksi data dilakukan pemilihan data yang akan digunakan didalam database. karena tidak semua data akan digunakan. Sumber data berasal dari Toko Berkah Baru, data yang didapat dari Toko Berkah Baru berupa Id transaksi dan nama barang. Dari data yang sudah disebutkan maka data yang dipilih untuk diproses yaitu nama barang dan Id transaksi.

\subsection{Data Transformation}

Dataset pada Tabel 4.1 akan diubah menjadi sebuah tabel itemset dari keseluruhan barang yang terjual agar sesuai untuk dilanjutkan ke proses data mining.

\subsection{Algoritma Apriori}

Proses pembentukan pola kombinasi itemsets dan pembuatan rules dimulai dari analisis data. Data yang digunakan adalah data aktifitas pelanggan, kemudian dilanjutkan dengan pembentukan pola kombinasi itemsets dan dari pola kombinasi itemsets yang menarik terbentuk association rules. Tahap dalam menganalisa data dengan Algoritma Apriori pada penjualan (data aktifltas pelanggan) dimulai dengan menyeleksi dan 
membersihkan data-data yang akan dianalisis, kemudian dicari semua jenis aktifltas yang ada didalam list transaksi penjualan, selanjut dicari jumlah setiap item yang ada pada semua data transaksi penjualan (data aktifltas pelanggan).

Pembentukan pola kombinasi didasarkan pada nilai support minimal dengan $6 \%$, Jika nilai support minimal $6 \%$ terpenuhi dan pola kombinasi itemsets yang ada lebih dari pada satu pola kombinasi, maka pola kombinasi itemsets yang berikutnya bisa bentuk. Setelah selesai pembuatan pola maka langkah selanjutnya pembentuk rules association dengan nilai minimal confidence $60 \%$.

\subsection{Analisa Pola Frekuensi Tinggi}

Pada tahap ini mencari kombinasi item yang memenuhi syarat minimum $6 \%$. Berikut tabel 1 dibawah ini yang merupakan tabel semua jenis item aktifitas pelanggan membeli barang:

\begin{tabular}{|c|c|c|}
\hline itemset & $\begin{array}{l}\text { Support } \\
\text { Count }\end{array}$ & Support \\
\hline Kantong Plastik & 10 & 32.25806 \\
\hline Bola Plastik & 1 & 3.225806 \\
\hline KorekGas & 1 & 3.225806 \\
\hline Jumbo & 1 & 3.225806 \\
\hline Rodeo & 2 & 6.451613 \\
\hline Kertas Nasi & 4 & 12.90323 \\
\hline Vaneli & 1 & 3.225806 \\
\hline Plastik 4x23 & 3 & 9.677419 \\
\hline Plastik 6x20 & 1 & 3.225806 \\
\hline Plastik $17 \times 40$ & 1 & 3.225806 \\
\hline Plastik 8x20 & 1 & 3.225806 \\
\hline Plastik 9×25 & 4 & 12.90323 \\
\hline Plastik 11×30 & 4 & 12.90323 \\
\hline Plastik 14x35 & 4 & 12.90323 \\
\hline Plastik 10x25 & 1 & 3.225806 \\
\hline Plastik $17 \times 40$ & 1 & 3.225806 \\
\hline Ager Swalow & 2 & 6.451613 \\
\hline Nutrijelly & 3 & 9.677419 \\
\hline Dus $18 \times 18$ & 1 & 3.225806 \\
\hline Dus 20x20 & 1 & 3.225806 \\
\hline Sedotan & 6 & 19.35484 \\
\hline Tusuk Gigi & 1 & 3.225806 \\
\hline Sendok Panjang & 2 & 6.451613 \\
\hline Solasi Hitam & 1 & 3.225806 \\
\hline
\end{tabular}

\begin{tabular}{|l|l|l|} 
Solasi Bening & 1 & 3.225806 \\
\hline Tali Rapia & 2 & 6.451613 \\
\hline Sterofom & 3 & 9.677419 \\
\hline Gilent Kuning & 3 & 9.677419 \\
\hline Gilet Blue & 1 & 3.225806 \\
\hline Karet & 3 & 9.677419 \\
\hline Okina & 3 & 9.677419 \\
\hline Celengan Plastik & 3 & 9.677419 \\
\hline Isi Steples & 1 & 3.225806 \\
\hline Tambang & 3 & 9.677419 \\
\hline Amplop & 1 & 3.225806 \\
\hline Lem Glu & 1 & 3.225806 \\
\hline Pengepel & 1 & 3.225806 \\
\hline Gula Miki & 1 & 3.225806 \\
\hline Citrun & 1 & 3.225806 \\
\hline Mika & 3 & 9.677419 \\
\hline Pasta Pandan & 1 & 3.225806 \\
\hline Karpet Plastik & 1 & 3.225806 \\
\hline Rolan & 2 & 6.451613 \\
\hline Mangkok Plastik & 5 & 16.12903 \\
\hline Sendok Bebek & 4 & 12.90323 \\
\hline Gelas 12ml & 1 & 3.225806 \\
\hline Gelas 14ml & 1 & 3.225806 \\
\hline Tutup Gelas & 1 & 3.225806 \\
\hline Sekat Plastik & 3 & 9.677419 \\
\hline Gelas Kopi & 1 & 3.225806 \\
\hline Gelas 16ml & 1 & 3.225806 \\
\hline Hail & & \\
\hline
\end{tabular}

Hasil perhitungan dari pencarian nilai support per item didapatkan dengan hasil tertinggi yaitu dengan nilai $32,2 \%$ dan sedangkan nilai terendah adalah sebesar $3,2 \%$. Minimum support yang ditentukan adalah 6\%. Maka terdapat 23 item yang tersisa yang memenuhi minimum support $6 \%$.

\subsection{Pembentukan Pola Kombinasi Dua Itemsets}

Pembentukan pola frekuensi dua itemsets dibentuk dari items aktifiktas pelanggan yang memenuhi support minimal yaitu dengan cara mengkombinasi semua items kedalam pola dua kombinasi.

Hasil dari pola pembentukan kombinasi dua itemsets yang dibentuk seperti tabel 3 dibawah ini:

Tabel 3 Tabel Kombinasi Dua Itemsets

\begin{tabular}{|c|c|c|}
\hline Item set & $\begin{array}{c}\text { support } \\
\text { count }\end{array}$ & Support \\
\hline
\end{tabular}




\begin{tabular}{|c|c|c|}
\hline kantong plastik, rodeo & 0 & 0 \\
\hline $\begin{array}{l}\text { kantong plastik, kertas } \\
\text { nasi }\end{array}$ & 0 & 0 \\
\hline $\begin{array}{l}\text { kantong plastik, plastik } \\
4 \times 23\end{array}$ & 0 & 0 \\
\hline kantong plastik, 9×25 & 0 & 0 \\
\hline kantong plasti, $11 \times 30$ & 1 & 3.225806452 \\
\hline $\begin{array}{l}\text { kantong plastik, plastik } \\
14 \times 35\end{array}$ & 1 & 3.225806452 \\
\hline $\begin{array}{l}\text { kantong plastik, ager } \\
\text { swalow }\end{array}$ & 0 & 0 \\
\hline $\begin{array}{l}\text { kantong plastik, } \\
\text { nutrijelly }\end{array}$ & 1 & 3.225806452 \\
\hline $\begin{array}{l}\text { kantoong plastik, } \\
\text { sedotan }\end{array}$ & 1 & 3.225806452 \\
\hline $\begin{array}{l}\text { kantong plastik, sendok } \\
\text { panjang }\end{array}$ & 0 & 0 \\
\hline $\begin{array}{l}\text { kantong plastik, tali } \\
\text { rapia }\end{array}$ & 1 & 3.225806452 \\
\hline $\begin{array}{l}\text { kantong } \\
\text { sterofom }\end{array}$ & 0 & 0 \\
\hline $\begin{array}{l}\text { kantong plastik, gilet } \\
\text { kuning }\end{array}$ & 0 & 0 \\
\hline kantong plastik, karet & 0 & 0 \\
\hline kantong plastik, okina & 0 & 0 \\
\hline $\begin{array}{l}\text { kantong plastik, } \\
\text { celengan plastik }\end{array}$ & 0 & 0 \\
\hline $\begin{array}{ll}\text { kantong } & \text { plastik, } \\
\text { tambang } & \\
\end{array}$ & 2 & 6.451612903 \\
\hline kantong plastik, mika & 1 & 3.225806452 \\
\hline kantong plastik, rolan & 1 & 3.225806452 \\
\hline $\begin{array}{l}\text { kantong plastik, } \\
\text { mangkok plastik }\end{array}$ & 1 & 3.225806452 \\
\hline $\begin{array}{l}\text { kantong plastik, sendok } \\
\text { bebek }\end{array}$ & 0 & 0 \\
\hline $\begin{array}{l}\text { kantong plastik sekat } \\
\text { plastik }\end{array}$ & 1 & 3.225806452 \\
\hline rodeo, kertas nasi & 0 & 0 \\
\hline rodeo, plastik $4 \times 23$ & 0 & $\underline{0}$ \\
\hline rodeo, plastik 9×25 & 0 & 0 \\
\hline rodeo, plastik $11 \times 30$ & 1 & 3.225806452 \\
\hline rodeo, plastik $14 \times 35$ & 1 & 3.225806452 \\
\hline rodeo, ager swalow & 0 & 0 \\
\hline rodeo, nutrijelly & 0 & 0 \\
\hline rodeo, sedotan & 1 & 3.225806452 \\
\hline rodeo, sedotan panjang & 0 & 0 \\
\hline rodeo, tali rapia & 0 & 0 \\
\hline rodeo, sterofom & 2 & 6.451612903 \\
\hline rodeo, gilet kuning & 0 & 0 \\
\hline rodeo, okina & 0 & 0 \\
\hline rodeo, celengan plastik & 0 & 0 \\
\hline rodeo, tambang & 0 & 0 \\
\hline
\end{tabular}

\begin{tabular}{|c|c|c|}
\hline rodeo, mika & 0 & 0 \\
\hline rodeo, rolan & 0 & 0 \\
\hline rodeo, mangkok plastik & 0 & 0 \\
\hline rodeo, sendok bebek & 0 & 0 \\
\hline rodeo, sekat plastik & 0 & 0 \\
\hline $\begin{array}{lll}\text { kertas } & \text { nasi, } & \text { plastik } \\
4 \times 23 & \end{array}$ & 0 & 0 \\
\hline $\begin{array}{l}\text { kertas nasi, plastik } \\
9 \times 25\end{array}$ & 0 & 0 \\
\hline $\begin{array}{lll}\text { kertas } & \text { nasi, } & \text { plastik } \\
11 \times 30 & & \\
\end{array}$ & 0 & 0 \\
\hline $\begin{array}{l}\text { kertas } \\
14 \times 35\end{array}$ & 0 & 0 \\
\hline $\begin{array}{lll}\begin{array}{l}\text { kertas } \\
\text { swalow }\end{array} & \text { nasi, } & \text { ager } \\
\end{array}$ & 0 & 0 \\
\hline kertas nasi, nutrijelly & 0 & 0 \\
\hline kertas nasi, sedotan & 0 & 0 \\
\hline $\begin{array}{l}\text { kertas nasi, sedotan } \\
\text { panjang }\end{array}$ & 1 & 3.225806452 \\
\hline kertas nasi, tali rapia & 1 & 3.225806452 \\
\hline kertas nasi, sterofom & 1 & 3.225806452 \\
\hline kertsa nasi, gilet kuning & 1 & 3.225806452 \\
\hline kertas nasi, karet & 0 & 0 \\
\hline kertas nasi, okina & 0 & 0 \\
\hline $\begin{array}{l}\text { kertas nasi, celengan } \\
\text { plastik }\end{array}$ & 0 & 0 \\
\hline kertas nasi, tambang & 0 & 0 \\
\hline kertas nasi, mika & 0 & 0 \\
\hline kertas nasi, rolan & 0 & 0 \\
\hline $\begin{array}{l}\text { kertas } \\
\text { plastik }\end{array}$ & 1 & 3.225806452 \\
\hline $\begin{array}{l}\text { kertas } \\
\text { bebek }\end{array}$ & 1 & 3.225806452 \\
\hline $\begin{array}{lll}\text { kertas } & \text { nasi, } & \text { sekat } \\
\text { plastik }\end{array}$ & 1 & 3.225806452 \\
\hline $\begin{array}{l}\text { plastik } 4 \times 23, \quad \text { plastik } \\
9 \times 25\end{array}$ & 0 & 0 \\
\hline $\begin{array}{lll}\text { plastik } & 4 \times 23, & \text { plastik } \\
11 \times 30 & \end{array}$ & 0 & 0 \\
\hline $\begin{array}{lll}\text { plastik } & 4 \times 23, & \text { plastik } \\
14 \times 35 & & \end{array}$ & 0 & 0 \\
\hline $\begin{array}{lll}\text { plastik } & 4 \times 23, & \text { ager } \\
\text { swalow }\end{array}$ & 1 & 3.225806452 \\
\hline plastik 4x23, nutrijelly & 0 & 0 \\
\hline plastik $4 \times 23$, sedotan & 0 & 0 \\
\hline $\begin{array}{l}\text { plastik } 4 \times 23 \text {, sedotan } \\
\text { panjang }\end{array}$ & 0 & 0 \\
\hline plastik $4 \times 23$,tali rapia & 0 & 0 \\
\hline plastik $4 \times 23$, sterofom & 0 & 0 \\
\hline $\begin{array}{lll}\text { plastik } & 4 \times 23, & \text { gilet } \\
\text { kuning }\end{array}$ & 0 & 0 \\
\hline plastik $4 \times 23$, karet & 0 & 0 \\
\hline plastik $4 \times 23$,okina & 0 & 0 \\
\hline
\end{tabular}




\begin{tabular}{|c|c|c|}
\hline $\begin{array}{l}\text { plastik } 4 \times 23 \text {, celengan } \\
\text { plastik }\end{array}$ & 0 & 0 \\
\hline plastik $4 \times 23$, tambang & 0 & 0 \\
\hline plastik 4×23, mika & 0 & 0 \\
\hline plastik $4 \times 23$, rolan & 0 & 0 \\
\hline $\begin{array}{l}\text { plastik } 4 \times 23 \text {, mangkok } \\
\text { plastik }\end{array}$ & 0 & 0 \\
\hline $\begin{array}{l}\text { plastik } 4 \times 23 \text {, sedotan } \\
\text { bebek }\end{array}$ & 0 & 0 \\
\hline $\begin{array}{lll}\text { plastik } & 4 \times 23, & \text { sekat } \\
\text { plastik }\end{array}$ & 0 & 0 \\
\hline $\begin{array}{lll}\text { plastik } & 9 \times 25, & \text { plastik } \\
11 \times 30 & & \end{array}$ & 0 & 0 \\
\hline $\begin{array}{ll}\text { plastik } & 9 \times 25, \text { plastik } \\
14 \times 35\end{array}$ & 0 & 0 \\
\hline $\begin{array}{l}\text { plastik } 9 \times 25, \quad \text { ager } \\
\text { swalow }\end{array}$ & 0 & 0 \\
\hline plastik 9x25, nutrijelly & 0 & 0 \\
\hline plastik $9 \times 25$, sedotan & 0 & 0 \\
\hline $\begin{array}{l}\text { plastik 9x25, sedotan } \\
\text { panjang }\end{array}$ & 1 & 3.225806452 \\
\hline plastik $9 \times 25$, tali rapia & 1 & 3.225806452 \\
\hline plastik 9×25, sterofom & 0 & 0 \\
\hline $\begin{array}{lll}\begin{array}{l}\text { plastik } \\
\text { kuning }\end{array} & 9 \times 25, & \text { gilet } \\
\end{array}$ & 1 & 3.225806452 \\
\hline plastik $9 \times 25$, karet & 2 & 6.451612903 \\
\hline plastik $9 \times 25$, okina & 0 & 0 \\
\hline $\begin{array}{l}\text { plastik } 9 \times 25 \text {, celengan } \\
\text { plastik }\end{array}$ & 1 & 3.225806452 \\
\hline plastik $9 \times 25$, tambang & 0 & 0 \\
\hline plastik $9 \times 25$, mika & 0 & 0 \\
\hline plastik 9x25, mika & 1 & 3.225806452 \\
\hline plastik $9 \times 25$, rolan & 0 & 0 \\
\hline $\begin{array}{l}\text { plastik 9x25, mangkok } \\
\text { plastik }\end{array}$ & 0 & 0 \\
\hline $\begin{array}{l}\text { plastik 9x25, sendok } \\
\text { bebek }\end{array}$ & 0 & 0 \\
\hline $\begin{array}{lll}\text { plastik } & 9 \times 25, & \text { sekat } \\
\text { plastik }\end{array}$ & 0 & 0 \\
\hline $\begin{array}{l}\text { plastik } 11 \times 30, \text { plastik } \\
14 \times 35\end{array}$ & 0 & 0 \\
\hline $\begin{array}{lll}\text { plastik } & 11 \times 30, & \text { ager } \\
\text { swalow }\end{array}$ & 0 & 0 \\
\hline plastik $11 \times 30$, nutrijelly & 0 & 0 \\
\hline plastik $11 \times 30$, sedotan & 3 & 9.677419355 \\
\hline $\begin{array}{l}\text { plastik } 11 \times 30 \text {, sedotan } \\
\text { panjang }\end{array}$ & 0 & 0 \\
\hline plastik $11 \times 30$, tali rapia & 0 & 0 \\
\hline plastik $11 \times 30$, sterofom & 1 & 3.225806452 \\
\hline $\begin{array}{lll}\text { plastik } & 11 \times 30, & \text { gilet } \\
\text { kuning }\end{array}$ & 0 & 0 \\
\hline plastik $11 \times 30$, karet & 1 & 3.225806452 \\
\hline plastik $11 \times 30$, okina & 1 & 3.225806452 \\
\hline plastik $11 \times 30$, celengan & 0 & 0 \\
\hline
\end{tabular}

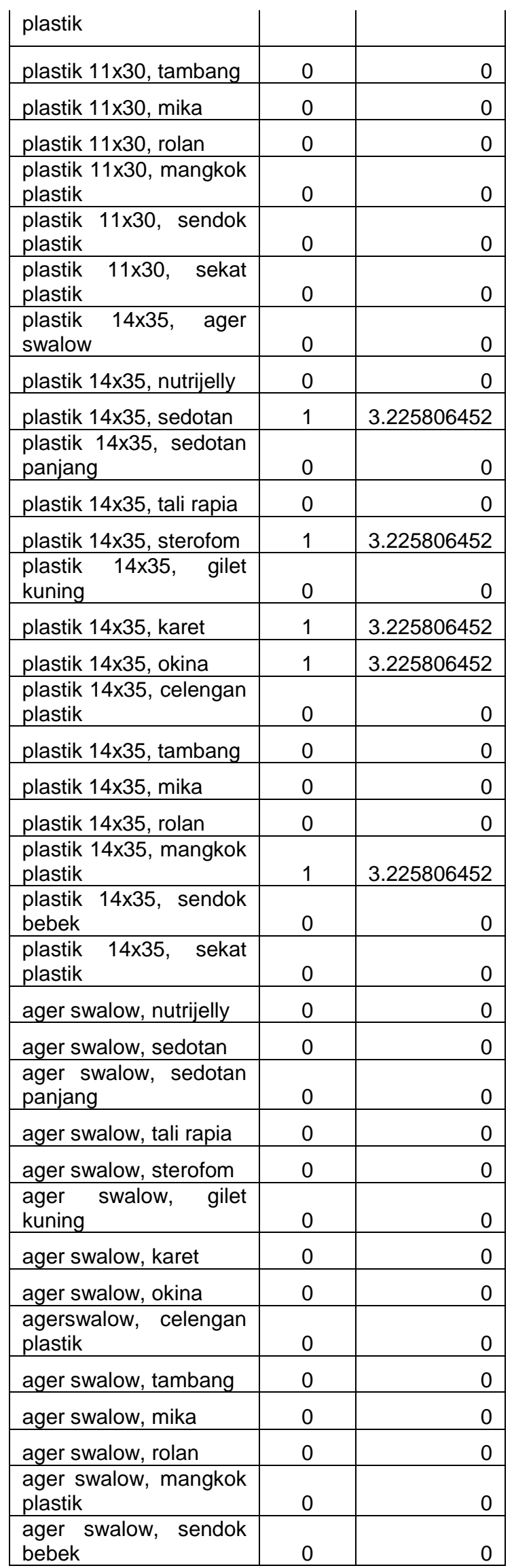




\begin{tabular}{|c|c|c|}
\hline $\begin{array}{l}\text { ager swalow, sekat } \\
\text { plastik }\end{array}$ & 0 & 0 \\
\hline nutrijelly, sedotan & 0 & 0 \\
\hline $\begin{array}{ll}\begin{array}{l}\text { nutrijelly, } \\
\text { panjang }\end{array} & \text { sedotan } \\
\end{array}$ & 0 & 0 \\
\hline nutrijelly, tali rapia & 0 & 0 \\
\hline nutrijelly, sterofom & 0 & 0 \\
\hline nutrijelly, gilet kuning & 1 & 3.225806452 \\
\hline nutrijelly, karet & 1 & 3.225806452 \\
\hline nutrijelly, okina & 0 & 0 \\
\hline $\begin{array}{l}\text { nutrijelly, celengan } \\
\text { plastik }\end{array}$ & 0 & 0 \\
\hline nutrijelly, tambang & 0 & 0 \\
\hline nutrijelly, mika & 0 & 0 \\
\hline nutrijelly, rolan & 0 & 0 \\
\hline $\begin{array}{ll}\begin{array}{l}\text { nutrijelly, } \\
\text { plastik }\end{array} & \text { mangkok } \\
\end{array}$ & 0 & 0 \\
\hline nutrijelly, sendok bebek & 0 & 0 \\
\hline nutrijelly, sekat plastik & 0 & 0 \\
\hline $\begin{array}{ll}\begin{array}{l}\text { sedotan, } \\
\text { panjang }\end{array} & \text { sendok } \\
\end{array}$ & 0 & 0 \\
\hline sedotan, tali rapia & 1 & 3.225806452 \\
\hline sedotan, gilet kuning & 1 & 3.225806452 \\
\hline sedotan, karet & 1 & 3.225806452 \\
\hline sedotan, okina & 1 & 3.225806452 \\
\hline $\begin{array}{ll}\begin{array}{l}\text { sedotan, } \\
\text { plastik }\end{array} & \text { celengan } \\
\end{array}$ & 1 & 3.225806452 \\
\hline sedotan, tambang & 0 & 0 \\
\hline sedotan, mika & 1 & 3.225806452 \\
\hline sedotan, rolan & 0 & 0 \\
\hline $\begin{array}{ll}\text { sedotan, } & \text { mangkok } \\
\text { plastik } & \\
\end{array}$ & 1 & 3.225806452 \\
\hline sedotan, sendok bebek & 0 & 0 \\
\hline sedotan, sekat plastik & 1 & 3.225806452 \\
\hline $\begin{array}{l}\text { sendok panjang, tali } \\
\text { rapia }\end{array}$ & 0 & 0 \\
\hline $\begin{array}{l}\text { sendok } \\
\text { sterofom }\end{array}$ panjang, & 1 & 3.225806452 \\
\hline $\begin{array}{l}\text { sendok panjang, gilet } \\
\text { kuning }\end{array}$ & 0 & 0 \\
\hline sendok panjang, karet & 0 & 0 \\
\hline sendok panjang, okina & 0 & 0 \\
\hline $\begin{array}{l}\text { sendok panjang, } \\
\text { celengan plastik }\end{array}$ & 0 & 0 \\
\hline $\begin{array}{ll}\text { sendok } & \text { panjang, } \\
\text { tambang } & \\
\end{array}$ & 0 & 0 \\
\hline sendok panjang, mika & 0 & 0 \\
\hline sendok panjang, rolan & 0 & 0 \\
\hline $\begin{array}{l}\text { sendok panjang, } \\
\text { mangkok plastik }\end{array}$ & 0 & $\underline{0}$ \\
\hline $\begin{array}{l}\text { sendok panjang, } \\
\text { sendok bebek }\end{array}$ & 0 & 0 \\
\hline
\end{tabular}

\begin{tabular}{|c|c|c|}
\hline $\begin{array}{l}\text { sendok panjang, sekat } \\
\text { plastik }\end{array}$ & 0 & 0 \\
\hline tali rapia, sterofom & 0 & 0 \\
\hline tali rapia, gilet kuning & 0 & 0 \\
\hline tali rapia, karet & 0 & 0 \\
\hline tali rapia, okina & 0 & 0 \\
\hline $\begin{array}{l}\text { tali rapia, celengan } \\
\text { plastik }\end{array}$ & 0 & 0 \\
\hline tali rapia, tambang & 0 & 0 \\
\hline tali rapia, mika & 0 & 0 \\
\hline tali rapia, rolan & 0 & 0 \\
\hline $\begin{array}{l}\text { tali rapia, mangkok } \\
\text { plastik }\end{array}$ & 0 & 0 \\
\hline tali rapia, sendok bebek & 0 & 0 \\
\hline tali rapia, sekat plastik & 0 & 0 \\
\hline sterofom, gilet kuning & 0 & 0 \\
\hline sterofom, karet & 0 & 0 \\
\hline sterofom,okina & 0 & 0 \\
\hline $\begin{array}{l}\text { sterofom, celengan } \\
\text { plastik }\end{array}$ & 0 & 0 \\
\hline sterofom, tambang & 0 & 0 \\
\hline sterofom, mika & 0 & 0 \\
\hline sterofom, rolan & 0 & 0 \\
\hline $\begin{array}{l}\text { sterofom, mangkok } \\
\text { plastik }\end{array}$ & 0 & 0 \\
\hline $\begin{array}{ll}\text { sterofom, } & \text { sendok } \\
\text { bebek }\end{array}$ & 0 & 0 \\
\hline sterofom, sekat plastik & 0 & 0 \\
\hline gilet kuning, karet & 1 & 3.225806452 \\
\hline gilet kuning, okina & 0 & 0 \\
\hline $\begin{array}{l}\text { gilet kuning, celengan } \\
\text { plastik }\end{array}$ & 0 & 0 \\
\hline gilet kuning, tambang & 0 & 0 \\
\hline gilet kunig, mika & 1 & 3.225806452 \\
\hline gilet kuning, rolan & 0 & 0 \\
\hline $\begin{array}{l}\text { gilet kuning, mangkok } \\
\text { plastik }\end{array}$ & 1 & 3.225806452 \\
\hline $\begin{array}{l}\text { gilet kuning, sendok } \\
\text { bebek }\end{array}$ & 0 & 0 \\
\hline $\begin{array}{lll}\text { gilet kuning, sekat } \\
\text { plastik }\end{array}$ & 0 & 0 \\
\hline karet, okina & 0 & 0 \\
\hline karet, celengan plastik & 1 & 3.225806452 \\
\hline karet, tambang & 0 & 0 \\
\hline karet, mika & 0 & 0 \\
\hline karet, rolan & 1 & 3.225806452 \\
\hline karet mangkok plastik & 0 & 0 \\
\hline karet, sendok bebek & 0 & 0 \\
\hline karet, sekat plastik & 0 & 0 \\
\hline
\end{tabular}




\begin{tabular}{|c|c|c|}
\hline okina, celengan plastik & 0 & 0 \\
\hline okina, tambang & 0 & 0 \\
\hline okina, mika & 0 & 0 \\
\hline okina, rolan & 0 & 0 \\
\hline okina, mangkok plastik & 1 & 3.225806452 \\
\hline okina, sendok bebek & 0 & 0 \\
\hline okina, sekat plastik & 1 & 3.225806452 \\
\hline $\begin{array}{l}\text { celengan } \\
\text { tambang }\end{array}$ & 0 & 0 \\
\hline celengan plastik, mika & 0 & 0 \\
\hline celengan plastik, rolan & 1 & 3.225806452 \\
\hline $\begin{array}{l}\text { celengann plastik, } \\
\text { mangkok plastik }\end{array}$ & 0 & 0 \\
\hline $\begin{array}{ll}\text { celengan } & \text { plastik, } \\
\text { sendok bebek } & \\
\end{array}$ & 0 & 0 \\
\hline $\begin{array}{l}\text { celengan plastik, sekat } \\
\text { plastik }\end{array}$ & 0 & 0 \\
\hline tambang, mika & 0 & 0 \\
\hline tambang, rolan & 0 & 0 \\
\hline $\begin{array}{ll}\text { tambang, mangkok } \\
\text { plastik }\end{array}$ & 1 & 3.225806452 \\
\hline
\end{tabular}

Data diatas merupakan kombinasi dua itemsets yang merupakan hasil dari dua kombinasi semua jenis itemsets yang ada keterhubungan barang dari jumlah transaksi, terdapat 4 kombinasi dua yang tersisa, karena memiliki minimum Support lebih dari $6 \%$.

\subsection{Pembentukan Association Rules}

Setelah semua pola frekuensi tinggi ditemukan, baru dicari association rules yang memenuhi syarat minimum confidence, dengan menghitung confidence aturan asosiasi $\mathrm{A}$ ke $\mathrm{B}$.

Berikut tabel 4 hasil pencarian nilai confidence terhadap tiap itemsets:

Tabel 4 Tabel Confidence Itemset

\begin{tabular}{|ll|c|c|}
\hline \multicolumn{1}{|c|}{ Item set } & $\begin{array}{c}\text { Proses } \\
\text { Confidence }\end{array}$ & Confidence \\
\hline $\begin{array}{l}\text { kantong plastik } \rightarrow \\
\text { tambang }\end{array}$ & $2 / 2$ & $100 \%$ \\
\hline $\begin{array}{l}\text { kantong plastik } \rightarrow \\
\text { rodeo }\end{array}$ & 0 & $0 \%$ \\
\hline $\begin{array}{l}\text { kantong plastik } \\
\text { sterofom }\end{array}$ & 0 & $0 \%$ \\
\hline $\begin{array}{l}\text { kantong plastik } \\
\text { plastik 9x25 }\end{array}$ & 0 & $0 \%$ \\
\hline $\begin{array}{l}\text { kantong plastik } \rightarrow \\
\text { karet plastik } \rightarrow\end{array}$ & 0 & $0 \%$ \\
\hline $\begin{array}{l}\text { kantong plastik } \rightarrow \\
\text { plastik 11x30 }\end{array}$ & $1 / 6$ & $17 \%$ \\
\hline $\begin{array}{l}\text { kantong kantong } \\
\text { sedotan }\end{array}$ & 0 & $0 \%$ \\
\hline $\begin{array}{l}\text { rodeo } \rightarrow \text { plastik } \\
\text { plan }\end{array}$ & \\
\hline
\end{tabular}

\begin{tabular}{|c|c|c|}
\hline rodeo $\rightarrow$ tambang & 0 & $0 \%$ \\
\hline rodeo $\rightarrow$ sterofom & $2 / 3$ & $67 \%$ \\
\hline rodeo $\rightarrow$ plastik $9 \times 25$ & 0 & $0 \%$ \\
\hline rodeo $\rightarrow$ karet & 0 & $0 \%$ \\
\hline rodeo $\rightarrow$ plastik $11 \times 30$ & $1 / 4$ & $25 \%$ \\
\hline rodeo $\rightarrow$ sedotan & $1 / 6$ & $17 \%$ \\
\hline $\begin{array}{l}\text { plastik } \quad 9 \times 25 \\
\text { kantong plastik }\end{array}$ & 0 & $0 \%$ \\
\hline $\begin{array}{lll}\begin{array}{l}\text { plastik } \\
\text { tambang }\end{array} & 9 \times 25 \quad \rightarrow \\
\end{array}$ & 0 & $0 \%$ \\
\hline plastik $9 \times 25 \rightarrow$ rodeo & 0 & $0 \%$ \\
\hline $\begin{array}{lll}\begin{array}{l}\text { plastik } \\
\text { sterofom }\end{array} & 9 \times 25 & \\
\end{array}$ & 0 & $0 \%$ \\
\hline plastik $9 \times 25 \rightarrow$ karet & $2 / 3$ & $67 \%$ \\
\hline $\begin{array}{l}\text { plastik } 9 \times 25 \rightarrow \text { plastik } \\
11 \times 30\end{array}$ & 0 & $0 \%$ \\
\hline $\begin{array}{lll}\begin{array}{l}\text { plastik } \\
\text { sedotan }\end{array} & 9 \times 25 & \rightarrow\end{array}$ & 0 & $0 \%$ \\
\hline $\begin{array}{l}\text { plastik } 11 \times 30 \quad \rightarrow \\
\text { kantong plastik }\end{array}$ & 0 & $0 \%$ \\
\hline $\begin{array}{lll}\begin{array}{l}\text { plastik } \\
\text { tambang }\end{array} & 11 \times 30 \rightarrow \\
\end{array}$ & 0 & $0 \%$ \\
\hline plastik $11 \times 30 \rightarrow$ rodeo & 0 & $0 \%$ \\
\hline $\begin{array}{ll}\begin{array}{l}\text { plastik } \\
\text { sterofom }\end{array} & 11 \times 30 \rightarrow \\
\end{array}$ & $1 / 3$ & $33 \%$ \\
\hline plastik $11 \times 30 \rightarrow$ karet & $1 / 3$ & $33 \%$ \\
\hline $\begin{array}{l}\text { plastik } 11 \times 30 \rightarrow \\
\text { plastik } 9 \times 25\end{array}$ & 0 & $0 \%$ \\
\hline $\begin{array}{lll}\text { plastik } & 11 \times 30 & \rightarrow \\
\text { sedotan } & & \end{array}$ & $4 / 3$ & $75 \%$ \\
\hline
\end{tabular}

Tabel diatas merupakan hasil pencarian dari nilai confidence tiap kombinasi itemset. Dengan menentukan nilai minimal confidence sebesar $60 \%$ maka didapat 4 sisa itemset, karena memiliki nilai lebih dari $60 \%$.

\subsection{Evaluasi}

Implementasi Pengujian Menggunakan Aplikasi Rapidminer Studio, hasil perhitungan seperti tabel 4 diatas dapat dilihat model Apriori dengan Framework Rapidminer Studio yaitu seperti gambar 2 dibawah ini:

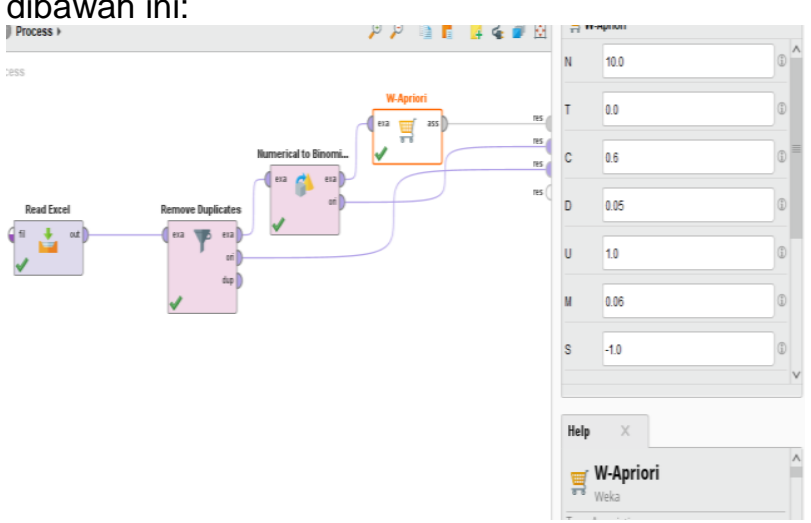

Gambar 2. Desain Model Apriori 
Pada Framework diatas sudah tersetting nilai minimal support $6 \%$ dan Nilai Confidence $60 \%$, sehingga jika model tersebut dijalankan maka akan didapatkan hasil seperti gambar 4.2 dibawah ini:

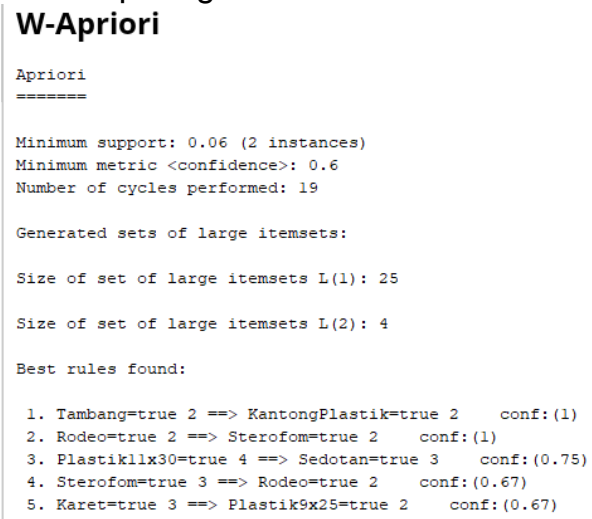

Gambar 3 Hasil Perhitungan Apriori dengan RapidMiner Studio

Pada gambar 3 terdapat 4 aturan asosiasi yang terbentuk. Maka dari gambar 3 dan tabel 4 hituangan secara manual tersebut dapat dibentuk sebuah aturan asosiasi pada Tabel 5 dibawah ini:

Tabel 5 Tabel Aturan Asosiasi

Jika membeli kantong plastik, maka membeli tambang

Jika membeli rodeo, maka membeli sterofom

Jika membeli plastik 9x25, maka membeli karet

Jika membeli plastik 11×30 maka membeli sedotan

\subsection{Knowledge}

Hasil dari analisis data mining diatas dapat digunakan untuk berbagai keperluan dalam penjualan, salah satunya yaitu untuk mengatur penempatan barang atau tata letak barang. Dari hasil diatas dapat disimpulkan bahwa dalam pengaturan tata letak dapat dilakukan dengan transaksi yang memiliki nilai confidence tinggi maka barang-barang yang terdapat dalam transaksi tersebut akan diletakan secara berdekatan. Kemudian transaksi yang memiliki nilai support tinggi akan diletakkan dibagian ujung/awal karena barang-barang dalam transaksi tersebut merupakan barang yang paling sering dibeli. Berikut tabel 6 hasil akhir penempatan barang:

Tabel 6. Hasil Akhir Untuk Penempatan Barang

\begin{tabular}{|l|c|}
\hline No & Penempatan Barang \\
\hline 1 & kantong plastik, tambang, rodeo, sterofom \\
\hline 2 & plastik $9 \times 25$, karet, plastik $11 \times 30$, sedotan \\
\hline
\end{tabular}

\begin{tabular}{|l|l|}
\cline { 2 - 3 } 3 & $\begin{array}{l}\text { sendok panjang, sterofom, mika, plastik } \\
4 \times 23, \text { nutrijelly }\end{array}$ \\
\hline 4 & tali rapia, rolan, celengan plastik \\
\hline 5 & $\begin{array}{l}\text { okina, kertas nasi, plastik 14x35, ager } \\
\text { swalow, sekat plastik }\end{array}$ \\
\hline
\end{tabular}

\section{Kesimpulan}

Berdasarkan hasil penelitian dapat disimpulkan bahwa setelah melakukan perhitungan menggunakan Algoritma Apriori maka didapatkan hasil aturan asosiasi 1 kombinasi itemsets tertinggi yaitu pelanggan membeli kantong plastik dengan support sebesar $32.2 \%$. Sedangkan nilai tertinggi pada 2 kombinasi itemsets adalah pelanggan yang membeli tambang pasti membeli kantong plastik dan pelanggan yang membeli plastik $11 \times 30$ pasti membeli sedotan dengan support sebesar 9,67\%. Untuk mengevaluasi hasil algoritma Apriori dilihat berdasarkan hasil aturan asosiasi dari 5 base rules yang memiliki njlai confidence diatas $60 \%$. Kemudian transaksi yang memiliki nilaj support tinggi akan diletakkan dibagian ujung/awal karena barang-barang dalam transaksi tersebut merupakan barang yang paling sering dibeli.

Untuk kepentingan penelitian selanjutnya, maka penulis memberikan saran yaitu bahwa algoritma apriori memiliki kelememahan yaitu membutuhkan waktu yang lama dalam proses pengolahannya, maka perlu menggunakan algoritma optimasi seperti FP (frequent pattern) Growth.

\section{Referensi}

Aditya, A., Marisa, F., \& Purnomo, D. (2016). Penerapan Algoritma Apriori Terhadap Data Penjualan di Toko Gudang BM. JOINTECS (Journal of Information Technology and Computer Science), 1(1), 1-5. https://doi.org/10.31328/jointecs.v111.40 8

Fajri, A. F. (2016). Implementasi Algoritma Apriori Dalam Menetukan Program Studi Yang Diambil Mahasiswa. Jurnal Iptek Terapan, 10(2), 81-85. https://doi.org/10.22216/jit.2016.v10i2.4 02

Gama, A. W. O., Putra, I. K. G. D., \& Bayupati, I. P. A. (2016). Implementasi Algoritma Apriori Untuk Menemukan Frequent Itemset Dalam Keranjang Belanja. Teknologi Elektro, 15(2), 21- 
26. https://doi.org/10.24843/mite.1502.04

Manurung, E. mining tingkat pesanan inventaris kantor menggunakan algoritma apriori pada kepolisian daerah sumatera utara, Hasugian, P. S., Studi, P., Informatika, T., Apriori, A., \& Algorithm, A. (2019). Data mining tingkat pesanan inventaris kantor menggunakan algoritma apriori pada kepolisian daerah sumatera utara. 4(2), 8-13.

Mardi, Y. (2017). Data Mining: Klasifikasi Menggunakan Algoritma C4.5. Jurnal Edik Informatika, 2(2), 213-219.

Nugraha, R. W., \& Hadiansah, R. (2017). penerapan data mining pada data transaksi distribusi untuk menganalisa penempatan buku menggunakan algoritma apriori ( Studi Kasus PT . Duta Bandung ). JATI, 2, 29-36.

Saefudin, S., \& Fernando, D. (2020). Penerapan Data Mining Rekomendasi Buku Menggunakan Algoritma Apriori.
JSil (Jurnal Sistem Informasi), 7(1), 50. https://doi.org/10.30656/jsii.v7i1.1899

Sari, P., \& Sinaga, B. (2018). Aplikasi Data Mining Dengan Menggunakan Algoritma Apriori Untuk Penjualan Produk Terbesar Pada Cv. Sakura Photo. Jurnal Mantik Penusa, 22(1), 34-38. Retrieved from http://ejurnal.pelitanusantara.ac.id/index.php/m antik/article/view/349

Thoriq Muhammad, A., \& Nurhadiyono, B. (2014). Penerapan Data Mining Pada Data Transaksi Penjualan Untuk Mengatur Penempatan Barang. Universitas Dian Nuswantoro. 